\title{
Hosting the Small Island Developing States: two scenarios
}

\author{
Milla Emilia Vaha \\ Faculty of Management, University of Tampere, Tampere, Finland
}

\begin{abstract}
Purpose - It has been estimated that some Small Island Developing States might have only decades before their territories become uninhabitable. Future of these states poses timely questions to world politics. The purpose of this paper is to examine the relationship between the potential hosts and endangered states at the time of relocation by looking at two relocation scenarios: Kiribati/New Zealand and the Maldives/Sri Lanka.
\end{abstract}

Design/methodology/approach - The paper uses normative international political theory to explore the nature of relocation. It critically examines the proposal for the free right to choose the new host state. Guided by two examples, the paper proposes that we should not ignore the contingent reasoning when evaluating these hypothetical scenarios.

Findings - The paper argues that the endangered state might have ethical grounds for its rightsclaims to continuous existence on a chosen territory. At the same time, both scenarios looked at here also impose serious constraints. By illustrating these constraints, the paper aims at mapping some central challenges that the continuity of endangered states creates to international state-system. The paper argues that the complex relationships between the potential hosts and the relocating communities should not be ignored.

Originality/value - This paper provides a contextual analysis of two hypothetical relocation scenarios. In doing so, it relies on comparative research in two regions and offers a normative argument in relation to the rights of both endangered and host populations.

Keywords Migration, Climate change, Relocation, International Relations, Small island states

Paper type Conceptual paper

\section{Introduction}

Sea-level rise affects Small Island Developing States. The International Panel on Climate Change noted the special vulnerability of island nations as early as 2001 (Hey et al., 2001). Low-lying atoll states such as the Marshall Islands and Kiribati in the South Pacific Ocean and the Maldives in the Indian Ocean are estimated to be at the greatest risk if sea-level rise continues. While no one can predict with certainty what will happen to these states should they be submerged beneath the ocean, relocation has been considered at least by the political leaders of these states as an alternative, and sometimes even the only plausible, imaginary[1]. In addition to migration, other alternatives, such as "nation ex-situ" (Burkett, 2013) and "continuous recognition" (Stoutenburg, 2015) have been explored in the legal literature as well. In each case, if the relocation becomes timely, the question of course is where are these people going to relocate? Some of the Small Island Developing States already have historical ties with

(C) Milla Emilia Vaha. Published by Emerald Publishing Limited. This article is published under the Creative Commons Attribution (CC BY 4.0) licence. Anyone may reproduce, distribute, translate and create derivative works of this article (for both commercial \& non-commercial purposes), subject to full attribution to the original publication and authors. The full terms of this licence may be seen at $\mathrm{http} / / /$ creativecommons.org/licences/by/4.0/legalcode

Received 6 October 2017 Revised 23 October 2017 29 October 2017 Accepted 31 October 2017 
IJCCSM 10,2 other states, such as the Marshall Islands to the USA or Niue and Tokelau to New Zealand[2]. Others, such as Tuvalu and Kiribati, have existing educational and labor schemes with their larger Pacific neighbors Australia and New Zealand.

Relocation is a complex political and legal matter. On the one hand, the rights of potential climate migrants need to be solved, as the contemporary international legal framework provides no protection for "climate refugees". On the other hand, if these states are going to continue their existence as states, the rights and obligations deriving from statehood on foreign land need to be reconsidered. Relocation is not only a matter of migrating individuals. It is provocatively also a matter of rights and responsibilities related to continuous existence as a political community. Whereas the proposals to relocate a certain amount of - or even all - citizens from the island communities to new host states seem plausible enough (given that we are only talking about less than a few million people who are at the highest risk), relocating political communities with continuing collective rights seems to be a different proposal altogether. It is a proposal that raises several interesting dilemmas from the perspective of international politics and law, both theoretically and in terms of political practice. Some of these questions have been discussed lately, predominantly by international lawyers (Gerrard and Wannier, 2013; McAdam, 2012a; Stoutenburg, 2015; Yamamoto and Esteban, 2014). The ethical challenges related to these potential relocation scenarios, however, have not yet been sufficiently explored.

To illustrate some of these ethical questions - and most importantly to contextualize them - the paper at hand looks at two previously proposed relocation scenarios: the Maldives relocation plan to Sri Lanka and Kiribati's plan to relocate its population to New Zealand. In both cases, the proposal has actually been made to relocate populations to new territories in prospective host countries. In both cases, one might argue, the endangered populations have strong ethical grounds for their rights-claims to continuous existence on a chosen territory. Both Kiribati and the Maldives are low-lying atoll states and considered by the United Nations as highly vulnerable. In both cases as well, the proposal is to relocate to a significantly larger neighboring country that has regional and cultural similarities with the endangered home state. In addition, in both cases, there is already a substantial migrated population from the island state in the suggested host country. The historical and communal ties of migration are therefore already in place, arguably helping the integration process of the greater population into their new homelands.

Yet, the existing arrangements allow only a certain, limited number of individuals to seek residency in these countries. These arrangements, it might be argued, are not sufficient when the majority of the i-Kiribati and Maldivian community need to leave their homeland. At the same time, both scenarios also impose other serious constraints. What is at stake here is the particular suitability of potential host state to accommodate the newcomers. Politically and culturally, there might be reasons such as economic capacity or domestic cohesion that have to be taken into account when considering the suitability of hosting endangered populations. Normatively, it also has to be considered if the proposed host country is the one that has the specific responsibility to welcome the incomers in the first place[3].

In my previous work on the right of Small Island Developing States to exist, I have theoretically explored the idea of continuous statehood through the potentially conflictual territorial rights-claims of Small Island Developing States and their new homelands in the event that the endangered state relocates to a territory that belongs to another state (Vaha, 2015). I have argued that the Small Island Developing States might have the right to continuous existence as states. If this is the case, there might also be a corresponding duty to enable this continuous existence. In the framework of the international state system, this responsibility falls to the states that are not at risk of state-extinction themselves. How do 
we determine which states have the responsibility to host the relocating island communities is not, however, straightforward.

By offering a comparative snapshot of the rights of both relocating and host populations in the two cases of Kiribati and the Maldives, this paper aims to map some central challenges that relocating endangered island communities might create in the context of the existing international system, a system that relies on the autonomy of sovereign states. As Jane McAdam has punctually noted in her work:

Whereas Pacific islanders could once move freely to other islands in times of resource scarcity or climate change, the legal (and sometimes physical) barriers to entry imposed by states today considerably restrict the freedom of movement (McAdam, 2012b, p.109).

This study is not only of academic interest: if the estimations of sea-level-rise are accurate, the question of relocation must be solved. In the world, in which the planet's surface is already divided into domestic territories by sovereign boundaries, the right to continuous existence of the political community without its own territory is going to be a controversial one.

It has to be noted from the outset that the discussion that follows is so far hypothetical. As pointed out above, no one knows with certainty what the future of Small Island Developing States will look like. These relocation imaginaries are not shared by all, perhaps not even by many in the endangered states[4]. The worst-case scenario has received some timely criticism in academic literature as well, quite deservedly so. McAdam, for one, argues that both academics and the island leaders have exploited "doomsday" vocabulary to portray an "Atlantis-style" alternative in which no one has any certainty (McAdam, 2012a, p. 123). Jon Barnett has noted that by portraying the situation of Small Island Developing States as solely one of relocation, more hopeful positive imaginaries are lost and not actively pursued in political practice (Barnett, 2017). The following paper agrees with both McAdam and Barnett that there are both political and normative problems in portraying the futures of Small Island Developing States as "doomsday" scenarios, with the most important challenge being that the citizens and leaders themselves do not unanimously support to this scenario across the island states. Interviews conducted with both the Maldivian and South Pacific leaders have pointed in this direction[5], as well as the previous research conducted on the local communities has done (Kelman, 2015; Kohtari, 2014; McAdam, 2012a). However, to explore the normative elements of potential relocation, which might or might not become a future reality for at least some part of these populations, this paper accepts the "doomsday scenario" for the sake of argument.

\section{Selecting the host state}

The worst-case scenario for the Small Island Developing States is that their territories become uninhabitable and the communities are forced to move. This paper explores this scenario. One of the key concerns of islanders has been that when the time comes, they must be able to "migrate with dignity[6]". The idea of "migration with dignity" includes two important components: the right to the continuous existence of endangered populations, and the global community's responsibility towards the Small Island Developing States. In the words of the former president of Kiribati, Anote Tong:

I have, time and time again, expressed my deep disappointment at the apparent lack of care by the many countries which can do the most to do something about this global scourge. I have even questioned the effectiveness of our international governance system in dealing with what is unquestionably an issue of survival which can only be addressed at the international level. How can we, in all conscience, and with all the science available to us, continue to regard this issue as a matter of sovereign right? Until we as a global community can commit to addressing this greatest 
IJCCSM

10,2

232

moral challenge, there can never be any credibility or sincerity in any of our other initiatives. (Tong, 2015a, p. 24, [sic], emphasis added).

“The government of Kiribati,” Jane McAdam has written:

Is keen to secure international agreements in which other states recognize that climate change has contributed to their predicament and acknowledge "relocation" as part of their obligations to assist (McAdam, 2012a, p. 200).

The state officials especially in the Pacific region have indeed argued on several occasions that the existential threat their countries now face is not only a matter of the right to exist but also actually a human rights matter. In the Suva Declaration from September 2015, the Pacific leaders urged the Conference of Parties in Paris to ensure "that human rights to exist as a people are protected (Pacific Island Development Forum, 2015, emphasis added)". Distinguished international voices, the United Nations Special Envoy on Climate Change Mary Robinson as an example, have repeatedly stressed that climate change definitely has a human rights dimension (Robinson, 2010). While one has to be cautious of interpreting the ethos of political leaders - who of course have their own political agendas, - the position taken by the islanders is indeed an interesting one. What they are fundamentally proposing is not only that climate change threatens their very existence as sovereign states but also that they have the human right to continue to exist as such corporeal bodies. The question then is how the global community can address this "greatest moral challenge of our time".

There has been an increasing interest in climate justice literature regarding responsibilities towards climate refugees, as well as on legal matters in the study of international law, especially related to the inundation of land. Many of these debates aim to offer some sort of compensation to endangered populations (Ödalen, 2014; Risse, 2009). In their recent chapter, Clare Heyward and Jörgen Ödalen make an interesting proposal according to which the citizens of Small Island Developing States should be offered a "passport for territorially dispossessed" that would give them the right to choose any particular country as their new homeland (Heyward and Ödalen, 2016, p. 209). According to Heyward and Ödalen, only through the freedom to choose to relocate wherever, could the islanders be offered a true compensation for their dilemma in which, by its nature, can never be properly compensated (as no one can offer the Small Island Developing States their islands back if they submerge underwater). "A full free choice," they argue, "is the "next best thing" (ibid, p. 213)".

According to the rationale of Hayward and Ödalen, being forced to migrate is obviously something one has the right to receive compensation for. Additionally, climate change that has fundamentally caused the forced relocation of Small Island Developing States is the responsibility of all states, and particularly of developed states. While different states have contributed differently to increasing greenhouse gas emissions, no state has a clean history with regard to pollution (Heyward and Ödalen, 2016, p. 218). Therefore, Hayward and Ödalen argue:

All states have international obligations towards stateless persons, regardless of the cause of statelessness, so a low-emitting state might have an obligation to accept those who are territorially dispossessed by climate change-induced sea-level-rise, regardless of their lack of historical responsibility (ibid, p. 219).

The last part of the sentence is central here, as it is often called for in climate justice literature that the greatest polluters should also bear the heaviest burdens concerning climate change adaptation and mitigation. This responsibility is commonly expressed by the "polluter pays principle". According to the principle, actors that contribute most 
to greenhouse gas emissions through extensive use of fossil fuels should also bear the greatest responsibility for the negative effects of climate change (Caney, 2009; Shue, 2014, pp. 180-194; Singer, 2002). Here, responsibility corresponds to the causal harm inflicted by the polluters. Causal responsibility as an idea is a rather simple one. According to casual responsibility, the duty-bearer has responsibility toward the rights-holder if (and only if) it has causally attributed to the harm of which the rightsholder is suffering. This form of responsibility corresponds quite neatly to our legal understanding of responsibility as a "contributory fault". As defined by Joel Feinberg, responsibility exists if, and only if, the responsible agent created/caused the harm in question (or at least their action substantially contributed to the harm, i.e. the harm occurred for the action of agent); the contributory conduct was in some way faulty (i.e. considered as blameworthy); and if the harmful action was truly the fault of the dutybearer (i.e. there is a link between the faulty action and the harm) (Feinberg, 1968, p. 674). Whereas causal responsibility as a principle is straightforward, its allocation in actual political practice is less so; what causal harms are we looking at that would trigger the application in which a polluter pays? What kind of action should be identified as a contributory fault, directly harming the Small Island Developing States and causing their actual relocation? When is the specific duty-bearer genuinely faulty for the harm[7]?

In an important legal decision from 2013, the New Zealand High Court declared that there are no grounds to seek refugee status in New Zealand based on climate change threats. Ioane TEITIOTA, a Kiribati citizen, had applied for refugee status for himself and his family (including three children who were born in New Zealand), on the grounds that his home country of Kiribati was no longer inhabitable in the longer term. However, the deciding judge found this reasoning unconvincing. First, many parts of Kiribati still are inhabitable; and second, there were no foundations for the claim that the high emitters, New Zealand included, would have had the intention to harm Kiribati (New Zealand High Court, 2013, p. 10). Thus, persecution by active human agency that it is required by the international refugee legislation for refugee status did not occur. To be blameworthy for harm, it can be argued, there needs to be the intention to harm. Obviously, such intention is hard if not impossible to confirm in international political practice, especially if we look at the processes of historical wrongdoing that have proceeded for the long term, such as is the case with climate change. Interestingly, the Small Island Developing States do not even necessarily base their argument for the right to relocation solely on the climate change threats. Kiribati, for instance, has made it clear that it would be "lobbying neighboring states like Australia and New Zealand for migration opportunities even if the climate change threat did not exist (former president Anote Tong in McAdam, 2012a, p. 203, emphasis in original)”. In these circumstances, it is important to think thoroughly the nature of responsibilities the other states have toward the Small Island Developing States, as well as the rights the endangered populations have to relocate.

Here, the need for a different kind of reasoning on climate responsibilities comes in. The proposal put forward by Heyward and Ödalen relies on universal responsibility: every state has the duty to accept the territorially dispossessed, even if some modifications could be made if the significant number of islanders had chosen a particular country as their new homeland (Heyward and Ödalen, 2016, pp. 220-222). While some (if not most) global climate responsibilities are universal - and are even identified as such by the UNFCCC through the concept of "common but differentiated responsibilities[8]" - this paper suggests that the right to choose a new homeland should also be evaluated in more particularistic terms, paying attention to the specific relationship that the potential host and endangered states
Small Island Developing States

233 
IJCCSM 10,2

have. While this form of reasoning relies more on contingent, rather than on moral, reasoning, these reasons are nonetheless crucially important in thinking about the peaceful future of both the endangered and the host state.

Following Heyward and Ödalen, there is a universal moral duty to relocate territorially dispossessed people. Because it is a moral duty, the objections of hosting cannot be based on economic and cultural constrains that could cause unfair burdens on hosting states. These reasons, they argue, are contingent, not moral. Heyward and Ödalen admit that there can be reasons for arguing that the right to choose a new home country unfairly distributes heavier burdens on some states than on others. However, at the same time, they also argue that these reasons have no real-life relevance, given the limited scale of the phenomenon and the means of (still non-existent) international compensation that the new host state could demand for its efforts to relocate islanders.

This work agrees with Heyward and Ödalen that the identification of the specific harmrelationship in historical terms might not be the most fruitful way of approaching the question of relocation. Historical and causal harms that have created the situation in which the Small Island Developing States find themselves cannot be easily identified, nor can we necessarily appoint blameworthiness of any kind. In fact, many of the affected societies do not even want to engage with futile "blame game" (McAdam, 2012a, p. 201). Thus, instead of appointing responsibilities and duties to host, it might be more fruitful to examine the suitability to host in further detail. Whereas in the case of New Zealand, to use our exemplary case, one could claim that the special responsibility of New Zealand to serve as the host country can be justified by its more developed status and its role in regional leadership, together with Australia (even without the intention to pollute and harm its island neighbors in particular), the same cannot be necessarily as easily said about Sri Lanka. The contingent objections should not be downplayed and the discussion below aims to illustrate why this is the case.

\section{Two relocation scenarios}

"Adaptation for Kiribati is beyond our borders. Relocation is by far the only adaptation option, this is where migration with dignity comes in (Tong, 2015b)", Tong stated during his plenary speech at the Pacific Island Development Forum's meeting in Suva in September 2015. Similarly, the relocation has been on the political agenda of the Maldives in the Indian Ocean as well. During the regime of former president Mohammed Nasheed, plans were on the table according to which Maldivians would relocate to either Sri Lanka, India or Australia at the time of the inundation of land[9]. To evaluate the two relocation scenarios and to avoid the "blame game" that might follow from the attribution of moral responsibilities to host, we need to look at the suitability of proposed new home countries, in this case Sri Lanka and New Zealand, to host the Maldives and Kiribati.

Suitability to host can be looked at through two characteristics of potential host countries: capacity and proximity. Capacity and proximity relate to the particular characteristics that the proposed states have to host newcomers. According to the accounts that underline capacity as a determinant factor of responsibility allocation, the most suitable agent is the one that has the best means to bear responsibility for those in need (Shue, 1996). Historically, the great powers in particular have been portrayed as the states most capable in material terms and therefore those having the greatest responsibilities in world politics (Brown, 2004). In the case, we are discussing here, capacity means the new host state's ability to accommodate the newcomers, both in social and economic terms. One could argue, for instance, that given that the majority of the Pacific Small Island Developing States are themselves listed as the least developed countries, it would be unreasonable to burden these 
societies by hosting Kiribati. Even Fiji, which has repeatedly expressed its interest in hosting its neighbors if needed and already has two islands with predominantly i-Kiribati and Tuvaluan populations, might not have sufficient capital (both social and economic) to do so[10].

In its report, "Pacific Possible: Labor Mobility", published in 2016, the World Bank proposes a new "Australia-New Zealand Atoll Access Agreement". The agreement would allow "open labor market access to the atoll countries most impacted by climate change and most in need of additional labor mobility opportunities (Kiribati and Tuvalu) to Australia Small Island Developing States and New Zealand (Curtain et al., 2016, p. 5)". According to the World Bank's vision, already existing limited open access arrangements must be expanded to include all the citizens in the most endangered nations - from Kiribati and Tuvalu in particular[11]. "The worsening impacts of climate change", the report states, "have provided a new moral imperative for providing open access (ibid., p. 30, emphasis added)". Whereas some limited migration agreements with Kiribati and Tuvalu are already in place, they are insufficient as the population growth in both of these endangered atoll states is very rapid while the erosion of habitable land is also rapidly expanding.

It is true that developed wealthy countries such as New Zealand and Australia could easily accommodate if not all, at least most, incoming islanders. In the words of Heyward and Ödalen, it is indeed important not to overestimate the numbers here (Heyward and Ödalen, 2016, p. 220). As of 2016, Kiribati has a population of 114,395[12]. While the number is high for a fragile low-lying atoll country such as Kiribati (which suffers severely from overcrowding), it would only be a 2 per cent increase to the current population of New Zealand. Likewise, in the case of Maldives and Sri Lanka, one could use the argument of the pre-existing Maldivian population in Sri Lanka. Approximately 10,000 Maldivians already live permanently in the country, predominantly in the Colombo area (Government of the Maldives, 2017). In numbers, 417,492 Maldivians would make up 2 per cent of the current 21.2 million Sri Lankans.

Unlike is the case with the developed state of New Zealand, one has to nonetheless critically evaluate the capacity of the developing state of Sri Lanka, recently ravaged by war, to host a large number of incoming migrants from the Maldives. Now, according to Heyward and Ödalen, it might be unlikely that all the Maldivians would even want to relocate to Sri Lanka in the first place and if they did, there should be an international mechanism in place to help Sri Lanka to relocate its neighbors. Following their proposal, a global compensation scheme would help to bear the costs of hosting endangered populations (Heyward and Ödalen, 2016, p. 221). Interestingly, the Maldives has a gross domestic product per capita over double that of Sri Lanka (\$8,601/3,835 in 2016) (World Bank, 2017). Perhaps one could argue that any relocation costs, at least in the case of wealthy endangered states such as the Maldives, should be borne by the relocating country itself. Of course, the primary income of the Maldives is tourism, which derives from its islands and climate change might significantly change the Maldivian revenues in the near future[13].

One particularly important counter-argument against Maldivian relocation to Sri Lanka relates to numbers, and especially to the numbers of ethnic background. While the Maldives is a Muslim country, Sri Lanka is home to all four major world religions. One might be able to assume that this heterogeneity would be an asset when considering the potential relocation of the Maldivian population. However, its relocation might be considered a threat to the existing ethnic populations as well. The reason for this derives from recent Sri Lankan history, another contingent reason that should not be underestimated when mulling over the relocation scenario in this particular case. Sri Lanka is still recovering from a long and violent civil war that was fought between the Liberation Tigers of Tamil Eelam and the 
IJCCSM

10,2

Buddhist state. It is unnecessary to go into detail here concerning the Sri Lankan civil war. The war took place in different stages between 1983 and 2009. The official Sri Lankan governmental opinion ever since the war has been that the war was not an ethnic conflict (United Nations, 2015). It is not nonetheless difficult to draw the conclusion that the war was between the predominantly Hindu Tamil population in the Northern and Eastern provinces and the Buddhist majority state in the Western parts of the country. Given the ethnic division on the battlefields, hesitancy to shake up the existing ethnic and religious balance in the country is understandable. According to the most recent census, 70.2 per cent of Sri Lankan population is Buddhist, 12.6 per cent Hindus, 9.7 per cent Muslim and 7.4 per cent Christians (Government of Sri Lanka, 2011). If all the Maldivians relocated to Sri Lanka tomorrow, that would increase the Muslim population close to 2.5 million people, a bit over 10 per cent of the overall population and close to the second biggest ethnicity (given that the Maldivians are all Muslims, which of course is not necessarily the case).

Whereas economic capacity is indeed a merely contingent factor, and may not therefore have a proper moral weight when thinking about the suitability to host endangered communities (especially if the global compensation scheme for host countries was introduced), identity is not. The identity is importantly also the basis for the "human right to exist as a people" that the islanders themselves call for. Here, the paper does not seek to display religion as a factor creating conflict at the time of relocation but it is an important factor for one's identity as an individual and as a citizen of a certain state.

In addition to capacity, then, one also has to look at the suitability of a host country for the endangered population in terms of proximity. This can mean geographical proximity, including similar climate conditions or cultural and social proximity, in terms of the likeness of the respective culture and traditions (including religion as discussed above). Heyward and Ödalen mention cultural closeness as one factor that might make territorially dispossessed populations choose one home country over another one. Here lies the major potential difficulty of their proposal, as it lacks a genuine sensitivity regarding the consequences of relocation to both relocating and hosting states by only placing emphasis on the needs and rights of the endangered. The relocating imaginaries are not short of tragedy. Yet, allocating responsibilities to host based on these imaginaries should not be done lightly, especially because the claim of Small Island Developing States is not only the claim to having their citizens relocated somewhere else. The passport of territorially dispossessed would not be enough when relocating communities were asking to have recognized standing as peoples as well. This is because the duty-claims made by the Small Island Developing States would not be limited to the new citizenship, as discussed by Heyward and Ödalen.

The greatest problem in Heyward and Ödalen's admirable and innovative proposal is that they consider the citizens of Small Island Developing States merely as a limited number of individuals looking for protection in new territories. This becomes evident at the very end of their paper where they imagine a potentially much larger relocation scenario, Bangladesh. In relation to Bangladesh, they argue: "unless a very large part of Bangladesh becomes submerged, the state of Bangladesh will continue to exist (Heyward and Ödalen, 2016, p. 222, emphasis added)". However, the moral claim put forward, at least by some of island leaders, toward the international community has precisely been one of continuous political existence. World history is full of examples of wars, civil conflicts and political turbulence over selfdetermination based on national and other forms of ethnic identity (one needs only to look at the recent events in Barcelona). In the words of the former prime minister of Tuvalu who argued strongly against relocation, Tuvaluans are "a proud nation of people with a unique culture which cannot be relocated somewhere else (Apisai Ielemia quoted in McAdam, 2012a, p. 145)”. Identity is a complex matter affecting both the host and the endangered 
nation, and in the case of relocation, it might be that these two identities can be in severe conflict with one another.

To evaluate the importance of proximity, let us consider another example. My home country Finland is by population a small (5.5 million people), although geographically large, state in the Northern Europe $\left(338,424 \mathrm{~km}^{2}\right.$, in average 16 people $/ \mathrm{km}^{2}$, the most sparsely populated country in Europe) (Statistics Finland, 2017). Hosting a great number of islanders as climate refugees would not be, in terms of capacity, too burdensome on a welfare state such as Finland. In fact, the original Alien Act from 2004[14] was one of the few immigration laws in the world that explicitly acknowledged international protection on the basis of environmental threat[15]. The Finnish land-ownership is also dependent on strong individual land-ownership rights; 60 per cent of Finnish forestry, for example, is privately owned (in comparison to 26 per cent owned by the state) (Finnish Forest Association, 2016). While the majority of land is privately owned, something called "everyone's right" ("jokamiehen oikeus" in Finnish) also exists whereby anyone can use land to pick berries or hunt game and fish, as long as no damage to the land is caused (and, in the case of hunting or fishing, one has acquired a license to do so). This right to use natural resources guarantees everyone the entitlement to benefit from nature, even in the case of privately owned land.

In many respects, then, Finland would make a great host for islanders looking for a new place to call home, perhaps even better than New Zealand or Sri Lanka. Not only does the country have the economic capacity to host more migrants than it currently does, but also the cultural traditions concerning land ownership and respect to land are also surprisingly similar to those in the Small Island Developing States. Would the islanders choose Finland as their home country? There are good reasons why they could, and perhaps should, do so. The quality of life in Finland is among the highest in the world (Organization for Economic Co-operation and Development, 2017), together with the enjoyment and protection of basic human rights. However, the reasons not to choose Finland to be the new home might be stronger than the ones to choose it, given the cultural and geographical distances that prevail between the Northern hemisphere Finland and tropical islands of Kiribati and the Maldives[16]. In the words of former president of the Maldives, Sri Lanka and India were chosen as potential new homelands "because they had similar cultures, cuisines and climates (The Guardian, 200810 November)”. The same can hardly be said about Finland. These reasons do not undermine the argument that the wealthy developed country Finland has specific responsibilities towards the weaker members of international society. It is just to say that making all-things-considered evaluations of, and suggestions for, future relocation and the duty to host, the differences and claims on both sides should be better taken into account when arguing either or[17]. While these cultural and climatic considerations, for instance, might at first seem "merely contingent", they do bear an important moral weight on decisions where to relocate - and, as we saw from the discussion on Sri Lanka, who to host as well.

A crucially important issue that needs to be taken better into consideration when thinking about the potential relocation scenarios is the traditional relationship people have to place, known as custom (kastom) in the South Pacific. While the colonial period changed the ownership-relations in what today are independent Pacific Small Island Developing States, the importance of custom for peoples' identity and relationship to their homeland is still significant. In the words of MacClancy, custom overlaps everything in the Pacific way of life: "kastom [...] is not merely an odd collection of dances and rituals, but a whole way of life that dictates almost all of one's actions and provides its own particular interpretation for almost everything that happens. It is complete unto itself. (MacClancy, 2002, p. 20)". The Pacific existence is very much about the existence from and with land: "People and their 
IJCCSM

10,2 ancestors grouped into clans, each of which lived on its own land. This ground, the physical embodiment of the metaphysical link between the past and present member of a clan, both provided the bones of people's ancestors and provided them with food. (Ibid., p. 21)". The same also applies to the Maldives (Kelman, 2015). Any sustainable relocation plan, therefore, has to accommodate the metaphysical attachments to a place that are enforced by the notion of traditional land ownership across the Small Island Developing States.

Again, this is something that Heyward and Ödalen touch upon, mainly through the work of Avner de-Shalit regarding relocation and identity. Following de-Shalit, Heyward and Ödalen argue that if it is the case that:

Place is partly constitutive of an individual's identity, and it important to protect individuals' senses of identity, then the territorially dispossessed should be provided with the means to construct a new identity in a new place (Heyward and Ödalen, 2016, p. 215).

They furthermore stress that because the new homeland chosen by the relocated population is not obviously their first choice (the first choice being their homeland) they need to be given free choice, so they can voluntarily choose the new place of identity. Some could indeed choose Finland. To relocate the political community of the Maldives or the political community of Kiribati to Finland would, however, be challenging because of several contingent yet ethically well-grounded reasons, reasons that all are founded on our identities: language, climate, religion and culture. It is also important to note that this would be challenging not only for the incoming population, but to the hosting one as well, a factor that is too often ignored in these debates (for an important exception on the ethics of immigration, Miller, 2016). Even regional proximity on its own cannot solve the issue of displaced identity, and this is why some islanders find it hard to contemplate relocation even to their closer neighbors, as it is the case with the i-Kiribati and New Zealand - or the i-Kiribati and Fiji. Thus, even the seemingly non-problematic[18] relocation scenario of New Zealand hosting its Pacific neighbor Kiribati might not be that non-problematic after all. Indeed, as it has been pointed out in the relation to the Marshallese relocation plans to the USA, the same concerns and anxieties relating to continuous identity, culture and selfdetermination prevail despite the easy access and existing communal ties (McAdam, 2012a, p. 36).

\section{Conclusions}

This paper has taken the initial steps in exploring the continuous existence of endangered low-lying atoll states from the perspective of potential relocation. By looking at two hypothetical, yet actually proposed scenarios of relocation, the paper has explored the relationship between endangered atoll states and their potential hosts. As we have seen, the responsibility-allocation between the host and endangered populations is problematic and direct causal links or harm-right relationships cannot be straightforwardly drawn.

The Small Island Developing States might have legitimate rights-claims toward international society concerning their continuous existence. It is clearly the case that the Small Island Developing States have not themselves significantly contributed to climate change and consequent sea-level-rise and should not be punished by stateextinction either. If there is a contributory fault, it does not (at least predominantly) rest on the endangered communities (although they of course are not completely "morally innocent" either[19]). Thus, the international community must take their claims for continuous existence seriously and if the time comes, there must be means to tackle the question of relocation. At the same time, it should not be forgotten - as it appears to 
often be the case in climate justice and legal literature - that any rights-claims put forward by the islanders are always claims against the rights-claims of other states and their citizens who also enjoy similar rights.

The rights and responsibilities we attach to solving the difficult questions relating to the future of Small Island Developing States should be carefully evaluated, as morality requires, by all sides. As Jane McAdam I believe well argues against the international climate refugee treaty, the key concern is the lack of political will. "It could be argued", she maintains, "that states might be prepared to adopt such an instrument precisely to call for shared responsibility. For example, an individual state might perceive a need to respond to potential arrivals of 'climate refugees', but be unwilling to unilaterally create legal avenues for their protection" (McAdam, 2012a, p. 198). Any multilateral action to share responsibility, however, do not replace or solve the lack of political will to tackle the issue. "A treaty [or a duty or right] per se does not "solve" the problem (ibid. p. 199)." The same applies to the freedom to choose the new home. The moral rights regarding the continuous existence of Small Island Developing States are often made in the literature from the perspective of low-lying atoll islands alone. Instead, what we would need are truly reciprocal proposals that do not become the prisoners of "blame game". The only way forward, it seems to me, is to seek for mutually beneficial political arrangements between the endangered communities and potential host states.

\section{Acknowledgements}

Over the past years, the author have fascinating discussions about the future of small island developing states with various people in various places, conversations that have no doubt influenced her thinking. She is especially indebted to all the islanders she has so far met during this research journey that is only in the beginning. In relation to this particular paper, the author thanks Stefano Moncada and Ilan Kelman for inviting her to contribute to this important Special Issue, and the reviewers for their valuable suggestions that made this paper publishable at last. An earlier version of this paper was presented at the European International Studies Association Conference in Barcelona 13-16 September 2017. The author is grateful for all those in the audience and especially to Matt McDonald for his engaging comments. Financially, the author was supported by Kone Foundation and the European Union's Erasmus Mundus Experts4Asia program. During the writing process, the author was regularly listening to Death Cab for Cutie's "Transatlanticism". The author sincerely hopes that the future of Small Island Developing States is not the one in which the ocean is eventually made where no island should go.

\section{Notes}

1. This paper considers relocation en masse, that is a scenario in which the whole population relocates to a new territory. The author acknowledges that, if and when relocation becomes timely, it is most likely to occur in phases and not at once. The most likely scenario for the citizens of low-lying atoll states, therefore, is a gradual resettlement - first domestically and regionally, and only then to other states, as Jane McAdam, for instance, has demonstrated (McAdam, 2012a,b). To explore this unlikely alternative is not meant to undermine the climate change adaptation and mitigation measures taken by the endangered low-lying atoll states (Barnett and Campbell, 2010).

2. The situation of Niue or the Marshall Islands, however, differs significantly from that of the Maldives or Kiribati, "since they already have a 'solution", namely, the access to New Zealand and the USA (McAdam, 2012a, p. 36). 


\section{IJCCSM 10,2}

3. In his recent concept paper for this journal, Bayes Ahmed argues in relation to Bangladesh that we might be able to identify states with the greatest responsibilities toward climate immigrants (Ahmed, 2017). This paper aims at challenging this kind of proposal by looking at the specific plans already in place.

4. Indeed, there are significant regional differences in perspectives on the likelihood of relocation. McAdam has pointed this out in her research, showing how the policies of Kiribati and Tuvalu in particular differ on the matter (McAdam, 2012a, pp. 202-207). The current Prime Minister of Tuvalu, Enel Sapoaga, underlined the position against the relocation as well. Interview with Enel Sapoaga in Suva on August 23, 2017.

5. This paper is a part of bigger project of the author on the Small Island Developing States and the existential threat. This research has been guided by "elite interviews" conducted by the author in Sri Lanka, the Maldives and the South Pacific region, between 2015 and 2017. Those interviewed have included various state-officials, including senior governmental officers and head of state. The purpose of these interviews has been to help to conceptualize the nature of "existential threat" the Small Island Developing States arguably now face, as well as to identify the responsibilities that the leaders of these states except to be fulfilled by the international community. The interviews were semi-structured and recorded or typed. The identity of interviewees has been withheld unless the permission to "go on record" has been explicitly given. Elite interviews, as has been noted by Glenn Beamer, are useful tools for constructing the beliefs of political actors (Beamer, 2002), which is why they have been used to guide the theoretical work in this project as well.

6. The leaders have underlined "migration with dignity" across the Pacific, the most vocal promoters being the recently deceased Tony de Brum of the Marshall Islands and the former president of Kiribati, Anote Tong.

7. Jenny Grote Stoutenburg has argued that because Small Island Developing States have not themselves contributed to the sea-level-rise through significant fossil fuel emissions, they should not be punished for them either. Grounding her proposal on the central legal principles of international law, Stoutenburg interestingly suggests that there might be at least a moral duty to continue recognizing Small Island States as states even at the time of inundation of their land. Here, Stoutenburg's argument relies on the ideas of causal responsibility and contributory harm. While she does not identify any particular agent as the duty-bearer for direct harm, she suggests that international society as a whole has the responsibility toward Small Island States to guarantee their continuing existence. (Stoutenburg, 2015, chapter 5). On a more general note, one could argue that because the contemporary climate justice debate seems to concentrate on responsibility for emissions, its practical applications are in a deadlock. While the Paris Agreement (United Nations Framework Convention on Climate Change, 2015) introduced both "loss and damage" - principle and mechanisms such as "global stock take" to follow-up the process of national governments, the future of the Agreement is yet to be seen, especially when one of the world's biggest emitters, the USA, has left the treaty.

8. According to the principle of "common but differentiated responsibilities", all humankind bears responsibility for the future of our planet, yet some actors (developed states) bear greater responsibility because of their greater contribution to the harm (United Nations, 1992).

9. Interestingly, there is no official documentation available on these relocation plans. When the author asked the question about the aforementioned relocation scenarios in the interviews with the Maldivian governmental officials, she was told that the plans were indeed made accordingly but that one could not find any official policy documents in which they would be laid out. The former president, Mohammed Nasheed, confirmed the existence of relocation plans under his regime. Interviews with anonymous governmental sources at the Ministry of Environment and Energy in Malé June 12, 2017 and with Nasheed in Colombo June 15, 2017. 
10. Prime Minister Bainimarama has regularly expressed Fiji's willingness to serve as a new home state to the endangered Pacific low-lying atoll states (Bainimarama, 2017). Its neighbors have not, however, appreciated Fiji's positioning itself as the leader of the region (Qounadovu, 2017).

11. Bilateral agreements between the United States, Australia and New Zealand and certain Small Island Developing States already exist. Citizens of the Marshall Islands and Palau have access to the American labor market and the citizens of Niue and the Cook Islands to New Zealand. As the World Bank notes, these arrangements are usually arranged upon joint history and cultural similarity (Curtain et al., 2016, p. 30).

12. All population figures here are from the World Bank (2016).

13. In the interviews with the Maldivian governmental officials, it became evident that the Maldives is not currently actually contemplating the possibility of relocation at all. When directly asked about the potential of Sri Lanka becoming a new home country for the displaced Maldivians, the answer was given that the Maldives's plan is not to lose its independence and sovereignty. The current governmental position is that the country would reclaim land rather than relocate. Interviews with the Maldivian governmental officials at the Ministry of Environment and Energy in Malè, 12 June 2017.

14. According to Article 88a of Aliens Act 301/2004, "an alien residing in Finland is issued a residence permit on the basis of humanitarian protection, if there are no grounds [...] for granting asylum or providing subsidiary protection, but he or she cannot return to his or her country of origin or country of former habitual residence as a result of an environmental catastrophe or a poor security situation, which may be because of an international or internal armed conflict or a poor human rights situation (Government of Finland, 2004, p. 32)".

15. The law has, however, been modified in 2016 and does not have the exact article anymore. In the travaux préparatoires from 2016 to amend the Act, however, the government explicitly states that this does not mean that the protection cannot be provided based on environmental threat under the modified law as well. According to the travaux préparatoires HE 2/2016, both groups and individuals could still be protected under other articles (Government of Finland, 2016).

16. The distance should not be however overestimated here. As the reviewer of this article interestingly noted to me, there are a great number of Marshallese living in Arkansas, United States. Arkansas is no more obvious of relocation destination to the Marshallese, in terms of proximity (excluding the fact that it is easy to the citizens of Marshall Islands to move to the United States due to the existing visa arrangements), than Finland would be to i-Kiribati.

17. The most well-known advocate of the national right to choose immigrants is David Miller, who has argued that democratic states must have the right to exclude people from their citizenry (Miller, 2016. See also a recent special issue with responses to his argument and Miller's reply in Parvin et al., 2017).

18. Given that there already exists a significant i-Kiribati population in New Zealand; the proximity of two countries in geographic terms; that New Zealand has already expressed its willingness to host the Pacific islanders by existing visa schemes; and New Zealand is a wealthy developed state and has sufficient means to serve as a host state.

19. Interestingly, there is a long history of perceiving especially the South Pacific region as the place of "innocence" and "indigenous purity", consequently destroyed by Western settlers. The "moral voice" of Small Island Developing States still very much relies on this imaginary of innocence; the publicly expressed idea that the region itself has done nothing to bear the horrendous consequences of climate change and should not therefore suffer for it either. While the narrative of innocence can (and should) be challenged as well (Vaha, 2017), it is important and plays a crucial role in relation to the normative negotiating power of Small Island Developing States in international global regimes such as the UNFCCC. The Pacific 
IJCCSM

10,2

Small Island Developing States, for example, already in the 1990s pushed for a category of "small and vulnerable economies" as a separate category from the United Nation's "least developed countries" category at the World Trade Organization (Morgan, 2015, p. 254). The nature of the "normative power" of Small Island Developing States is a fascinating research topic on its own and needs to be studied further.

References

Ahmed, B. (2017), "Who takes responsibility for the climate refugees?", International Journal of Climate Change Strategies and Management (open access), available at: https://doi.org/10.1108/IJCCSM10-2016-0149

Bainimarama, V. (2017), Key Address at the Climate Action Pacific Partnership Event, Suva 3 July, 2017, Field note.

Barnett, J. (2017), "The dilemmas of normalizing losses from climate change: towards hope for pacific atoll countries", Asia Pacific Viewpoint, Vol. 58 No. 1, pp. 3-13.

Barnett, J. and Campbell, J. (2010), Climate Change and Small Island States: Power, Knowledge and the South Pacific, Earthscan, New York, NY.

Beamer, G. (2002), "Elite interviews and state politics research", State Politics and Policy Quarterly, Vol. 2 No. 1, pp. 86-96.

Brown, C. (2004), "Do great powers have great responsibilities? Great powers and moral agency", Global Society, Vol. 18 No. 1, pp. 5-19.

Burkett, M. (2013), "The Nation Ex-Situ”, in Gerrard, M. and Wannier, G. (Eds), Threatened Island Nations: Legal Implications of Rising Seas and a Changing Climate, Cambridge University Press, Cambridge, pp. 89-121.

Caney, S. (2009), "Justice and the distribution of greenhouse gas emissions", Journal of Global Ethics, Vol. 5 No. 2, pp. 125-146.

Curtain, R., Dornan, M., Doyle, J. and Howes, S. (2016), Pacific Possible. Labour Mobility: The Ten Billion Dollar Prize, World Bank Report of July 2016, available at: http://pubdocs. worldbank.org/en/555421468204932199/pdf/labour-mobility-pacific-possible.pdf (accessed 27 September 2017).

Feinberg, J. (1968), “Collective responsibility”, Journal of Philosophy, Vol. 65 No. 21, pp. 674-688.

Finnish Forest Association (2016), "Forest ownership", available at: www.smy.fi/en/forest-fi/forestfacts/finnish-forests-owned-by-finns/ (accessed 2 August 2017).

Gerrard, M.B. and Wannier, G.E. (Eds) (2013), Threatened Island Nations: Legal Implications of Rising Seas and $a$ Changing Climate, Cambridge University Press, Cambridge.

Government of Finland (2004), Aliens Act 301/2004, available at: www.finlex.fi/fi/laki/kaannokset/ 2004/en20040301.pdf (accessed 27 July 2017).

Government of Finland (2016), Hallituksen esitys HE 2/2016, available at: www.eduskunta.fi/FI/vaski/ HallituksenEsitys/Sivut/HE_2 \pm 2016 .aspx (accessed 27 July 2017).

Government of Sri Lanka (2011), "The census of population and housing of Sri Lanka", available at: www. statistics.gov.lk/PopHouSat/CPH2011/index.ph/fileName=pop43\&gp=Activities\&tpl= $($ accessed 2 August 2017).

Government of the Maldives (2017), "Maldives embassy to Colombo", Sri Lanka website, available at: http://maldivesembassy.lk/mecc (accessed 2 July 2017).

Hey, J.E., Suarez, A.G., Wong, P.P., Briguglio, L. and Ragoonaden, S. (2001), "Small Island States", in McGarthy, J.J., Canziani, O.F., Leary, N.A., Dokken, D.J., White, K.S. (Eds), Intergovernmental Panel on Climate Change, Climate Change 2001: Impacts, Adaptation and Vulnerability (Contribution of Working Group II to the Third Assessment Report of the 
Intergovernmental Panel on Climate Change), Cambridge University Press, Cambridge, pp. 843-875.

Heyward, C. and Ödalen, J. (2016), "A free movement passport for the territorially dispossessed", in Heyward, C. and Roser, D. (Eds), Climate Justice in a Non-Ideal World, Oxford University Press, Oxford, pp. 208-226.

Kelman, I. (2015), "Difficult decisions: migration from small island developing states under climate change", Earth's Future, Vol. 3 No. 4, pp. 133-142.

Kohtari, U. (2014), "Political discourses of climate change and migration: resettlement policies in the Maldives", The Geographical Journal, Vol. 180 No. 2, pp. 130-140.

MacClancy, J. (2002), To Kill a Bird with Two Stones, Vanuatu Cultural Centre, Port Vila.

McAdam, J. (2012a), Climate Change, Forced Migration, and International Law, Oxford University Press, Oxford.

McAdam, J. (2012b), "Disappearing states', atatelessness and the boundaries of international law", in McAdam, J. (Ed.), Climate Change and Displacement: Multidisciplinary Perspectives, Hart Publishing, Oxford, pp. 105-129.

Miller, D. (2016), Strangers in Our Midst: The Political Philosophy of Immigration, Harvard University Press, Cambridge, MA.

Morgan, W. (2015), "Negotiating power in contemporary pacific trade diplomacy", in Fry, G. and Tarte, S. (Eds), The New Pacific Diplomacy, Australian National University Press, Canberra, pp. 251-261.

New Zealand High Court (2013), Ioane Teitiota vs the Chief Executive of the Ministry of Business, Innovation and Employment of 16.10.2013 CIV-2013-404-3528 [2013] NZHC 3125, available at: https://forms.justice.govt.nz/search/Documents/pdf/jdo/56/alfresco/service/api/node/ content/workspace/SpacesStore/6f4d600a-373f-4ff8-8ba1-500fb7cc94b0/6f4d600a-373f-4ff8-8ba1500fb7cc94b0.pdf (accessed 2 October 2017).

Ödalen, J. (2014), "Underwater self-determination: sea-level rise and deterritorialized small island states", Ethics, Policy \& Environment, Vol. 17 No. 2, pp. 225-237.

Organization for Economic Co-operation and Development (2017), "Better life index: Finland", available at: www.oecdbetterlifeindex.org/countries/finland/ (accessed 16 October 2017).

Pacific Island Development Forum (2015), Suva Declaration on Climate Change, issued at the 3rd PIDF Leaders Summit 2-4 September 2015 in Suva, Fiji Islands, available at: http://pacificidf.org/wpcontent/uploads/2013/06/PACIFIC-ISLAND-DEVELOPMENT-FORUM-SUVA-DECLARATIONON-CLIMATE-CHANGE.v2.pdf (accessed 25 October 2017).

Parvin, P., Miller, D., Kukathas, C., Fine, S., Kollar, E., Straehle, C., Owen, D. and Angeli, O. (2017), "Symposium on David miller's strangers in our midst: the political philosophy of immigration", Critical Review of International Social and Political Philosophy, Vol. 20 No. 6, pp. 697-773.

Qounadovu, S. (2017), "Tuvalu prime minister: relocation not the answer to climate change", Pacific Island Report Online Portal, available at: www.pireport.org/articles/2017/07/03/tuvalu-primeminister-relocation-not-answer-climate-change (accessed 6 October 2017).

Risse, M. (2009), "The right to relocation: disappearing island nations and common ownership of the earth", Ethics \& International Affairs, Vol. 23 No. 3, pp. 281-300.

Robinson, M. (2010), "Foreword", in Humphreys, S. (Ed.), Human Rights and Climate Change, Cambridge University Press, Cambridge, pp. xvii-xvxx.

Shue, H. (1996), Basic Rights: Subsistence, Affuence, and the US Foreign Policy, Princeton University Press, Princeton.

Shue, H. (2014), Climate Justice: Vulnerability and Protection, Oxford University Press, Oxford.

Singer, P. (2002), One World: The Ethics of Globalization, Text Publishing, Melbourne.

Statistics Finland (2017), "Statistics Finland”, available at: www.stat.fi/org/index_en.html (accessed 5 October 2017). 
IJCCSM

10,2

Stoutenburg, J. (2015), Disappearing Island States in International Law, Brill Nijhoff, Leiden.

The Guardian (2008), "Paradise almost lost: Maldives seek to buy a new homeland", 10 November 2008, available at: www.theguardian.com/environment/2008/nov/10/maldives-climate-change (accessed 17 October 2017).

Tong, A. (2015a), "Charting its own course': a paradigm shift in pacific diplomacy", in Fry, G. and Tarte, S. (Eds), The New Pacific Diplomacy, Australian National University Press, Canberra, pp. 21-24.

Tong, A. (2015b), Address to the Pacific Island Development Forum Leaders Meeting, September 2-4, Field notes, Suva.

United Nations (1992), "The Rio declaration on environment and development of 12 august 1992”, A/ CONF.151/26, Vol. I, available at: www.un.org/documents/ga/conf151/aconf15126-1annex1.htm (accessed 2 October 2017).

United Nations (2015), Comprehensive Report of the Office of the United Nations High Commissioner for Human Rights on Sri Lanka of 28 September 2015, A/HRC/30/61, available at: www.ohchr.org/ EN/HRBodies/HRC/Pages/OISL.aspx (accessed 5 October 2017).

United Nations Framework Convention on Climate Change (2015), Paris Agreement as Contained in the Report of the Conference of the Parties in its Twenty-First Session, FCCC/CP/2015/10/Add.1, available at: http://unfccc.int/meetings/paris_nov_2015/items/9445.php (accessed 22 March 2016).

Vaha, M.E. (2015), "Drowning under: small Island states and the right to exist", Journal of International Political Theory, Vol. 11 No. 2, pp. 206-223.

Vaha, M.E. (2017), "We as peoples have the right to exist: threatened nations and climate justice", Pacific Affairs, Vol. 90 No. 4, pp. 767-776.

World Bank (2016), "Population, total", available at: https://data.worldbank.org/indicator/SP.POP. TOTL (accessed 27 July 2017).

World Bank (2017), “GDP per capita (current US\$)”, available at: https://data.worldbank.org/indicator/ NY.GDP.PCAP.CD (accessed 17 October 2017).

Yamamoto, L. and Esteban, M. (2014), Atoll Island States and International Law: Climate Change Displacement and Sovereignty, Springer Verlag, Berlin.

\section{Further reading}

Death Cab for Cutie (2003), "Transatlanticism," song from studio album Transatlanticism, lyrics by Gibbard, B. and Walla, C. Barsuk Records, Seattle, WA.

\section{About the author}

Milla Emilia Vaha is currently a Senior Lecturer in International Relations at the University of Tampere, Finland. Her research focuses on the ethics of world politics, and her areas of specialization include the ethics of war, global justice and Immanuel Kant's political philosophy. In her current research, she explores the future of small island states threatened by climate change, and she has conducted comparative research in the South Pacific and Indian Ocean regions. Her publications include edited chapters and articles in journals such as the Journal of International Political Theory, International Politics and Journal of Military Ethics. Milla Emilia Vaha can be contacted at: mevaha@, utu.fi

For instructions on how to order reprints of this article, please visit our website:

www.emeraldgrouppublishing.com/licensing/reprints.htm

Or contact us for further details: permissions@emeraldinsight.com 